\title{
Some observations on an atypical planktic foraminifer from the Middle Eocene of Kutch, India
}

\author{
Sonal Khanolkar* \& Pratul Kumar Saraswati \\ Department of Earth Sciences, Indian Institute of Technology Bombay, Mumbai 400076, India \\ *Correspondence: sonal.k.12@gmail.com
}

\begin{abstract}
An atypical planktic foraminifer having close resemblance with Orbulinoides Blow \& Saito, 1968 is recorded from a lignite mine section in Kutch, western India. It is practically indistinguishable from Orbulinoides under optical microscope due to general similarities in chamber morphology, coiling mode, aperture number and character, but differs in wall texture when observed under scanning electron microscope (SEM). The wall is characterized by pores of variable size and irregularly distributed pustules unlike the spinose wall of normal Orbulinoides. Based on the SEM micrographs some specialist opinion suggested that the taxon might be a benthic foraminifer. The morphological features of the studied foraminifera are, however, distinctly different from benthic foraminifera with a planktic stage. The associated larger benthic foraminifera correlate the section with the carbonates of Middle Eocene (Bartonian) age in the adjoining areas of Kutch. The accompanying foraminiferal assemblage suggests a near-shore, brackish-water, semi-enclosed depositional environment. It is suggested that the aberrant wall texture was possibly due to environmental stress developed in the restricted basin. Due to incongruous wall texture and to its occurrence as the only planktic foraminifera in the section, the nomenclature of the reported foraminifera is kept open.
\end{abstract}

Keywords: Orbulinoides; atypical wall structure; Middle Eocene; Kutch

Supplementary material: List of Matanomadh foraminiferal distribution is available at http://www.geolsoc.org.uk/ SUP18861

Received 29 January 2015; accepted 22 March 2015

The planktic foraminifera belonging to the subfamily Porticulasphaerinae (Banner 1982) of the Globigerinacea comprise genera typically characterized by trochospiral to streptospiral tests in which the final globular chamber almost completely embraces the previous coils. Orbulinoides Blow \& Saito, 1968 is a monotypic genus of this subfamily and it is an important age-diagnostic marker of the Middle Eocene. Orbulinoides beckmanni (Saito, 1962) has a short stratigraphic range of less than 1 myr and defines the Zone P13 (Berggren et al. 1995) and E12 (Wade et al. 2011). The species was initially recognized as 'Porticulasphaera beckmanni' by Saito (1962) and the generic name was later amended to Orbulinoides new genus by Blow \& Saito (1968) (see also Cordey 1968). Proto Decima \& Bolli (1970) considered that O. beckmanni evolved from the lineage Globigerinatheka curryi Proto Decima \& Bolli, 1970 and Globigerinatheka euganea Proto Decima \& Bolli, 1970 and it shows variations such as bulla-like structures and areal apertures. Orbulinoides beckmanni was geographically confined to the tropical and warm mid-latitudes (Premoli Silva et al. 2006). During the study of samples from a lignite mine in Kutch, western India we recorded a foraminifer sharing many superficial characteristics with the planktic foraminifera $O$. beckmanni under the optical microscope but when observed under scanning electron microscope (SEM) it showed a distinctly different wall texture. The presence of Orbulinoides in the samples is not unexpected, considering its common occurrence in other sections of this region (Mohan \& Soodan 1970; Samanta 1970) and due to the association of larger benthic foraminifera of Middle Eocene age in the studied samples. Initially we discussed this form with several specialists on planktic foraminifera due to (i) its wall structure that is not normally seen in Orbulinoides and (ii) its occurrence as the only planktic foraminifer from several levels in the mine section. Based on the illustrations provided by us, opinion was divided from 'phylogenetically advanced forms of $O$. beckmanni' and 'degenerative features of $O$. beckmanni' to 'a probable benthic foraminifer'. In view of this, we report and illustrate these atypical forms for wider perusal. The unusual wall texture, being the only planktic foraminifer in the section, and the divergent views of specialist colleagues do not permit us to firmly assign it to a known or new genus/species. We, therefore, keep the nomenclature open and describe and illustrate this atypical planktic foraminifer for wider consultation.

\section{Material and methods}

The Eocene succession of Kutch largely developed as a carbonate platform under a stable, open marine environment. However, some land-locked basins developed in the early phase when the sea transgressed over the uneven land surface of the Deccan country where sedimentation occurred in restricted environments (Biswas $\&$ Raju 1971). These sub-basins are known for their commercial occurrence of lignite. The succession in Matanomadh lignite mine (N 2330', E 68 55') (Fig. 1a) consists of $4 \mathrm{~m}$ of lignite in the lower part and $8 \mathrm{~m}$ of shales and mudstones in the upper part. Variegated clays overlying the mudstone are devoid of fossils (Fig. 1b). Twenty-three samples were collected at a $50 \mathrm{~cm}$ interval on average from across the mine face.

For separation of foraminifera a spoonful of sodium carbonate was added to the samples and boiled for about one hour. The disaggregated sample was washed under a jet of water over a $63 \mu \mathrm{m}$ sieve. The residue was dried in the oven at $60^{\circ} \mathrm{C}$. Around $20-30$ specimens of the unnamed planktic foraminifera reported in this paper were picked from each sample. For comparison with our debated specimens, we also picked confirmed O. beckmanni from Fulra Limestone (Samanta 1970) in the Berwali river section (Fig. 1a). 
(a)

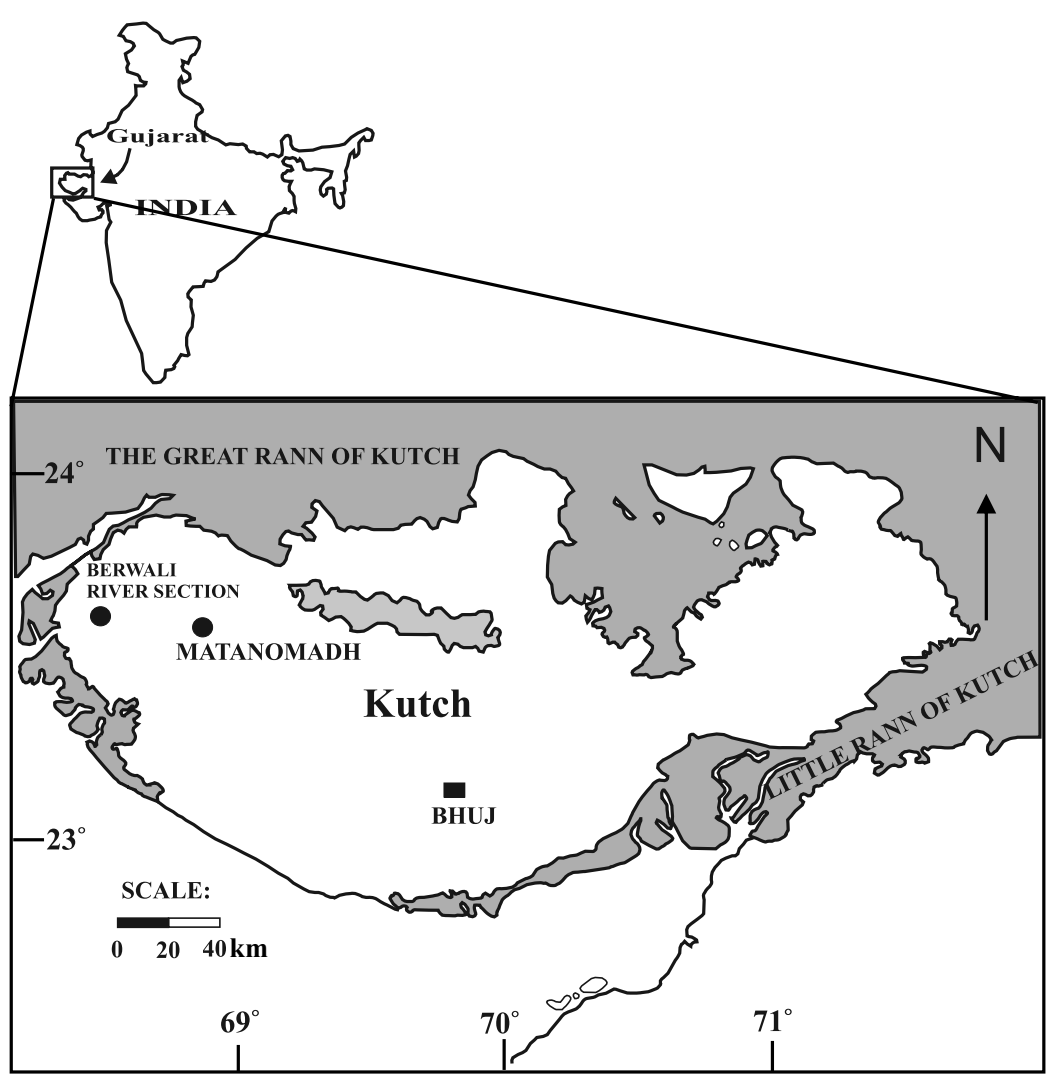

(b)

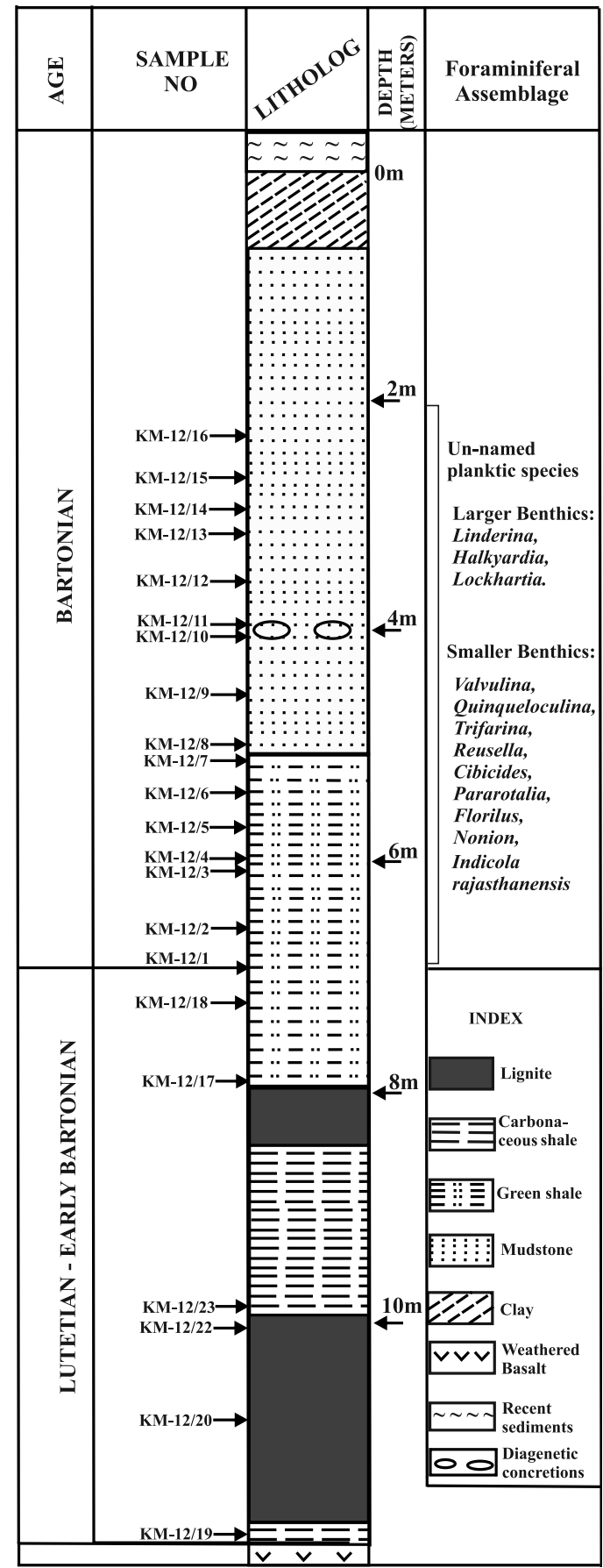

Fig. 1. (a) Location of Matanomadh mine and Berwali river section, Kutch, western India. (b) Lithological column of the Matanomadh mine section. Sample points indicated by horizontal arrows.

SEM micrographs of the specimens were taken to illustrate the morphological variations. The first 300 specimens of foraminifera were picked from the representative splits of the processed mine section samples to study the associated fauna and determine the palaeodepositional conditions. We used PAST package (Hammer et al. 2001) to calculate the Shannon-Weaver $(\mathrm{H})$ and Fisher alpha $(\alpha)$ diversity indices. We followed Singh \& Kalia (1970), Murray \& Wright (1974), Kalia (1978) and Loeblich \& Tappan (1987) for identification of the foraminiferal species. We divided the smaller benthic foraminifera into the morphogroups given by Nagy (1992), Preece et al. (1999), Nigam et al. (2007) and Reolid et al. (2008) for palaeoenvironmental interpretation. The foraminifera of the studied sections belong to the following two morphogroups:
1. Rectilinear Benthic Foraminifera (RBF of Nigam et al. 2007) consisting of genera with biserial, triserial or uniserial chamber arrangement, large-sized pores in the test wall and an infaunal mode of living;

2. Rounded Benthic Foraminifera (RoBF of Nigam et al. 2007) consisting of genera with trochospiral or planispiral chamber arrangement and an epifaunal mode of living.

Prior to imaging, the specimens were gold coated and the SEM micrographs were taken using a FEI QUANTA-200 instrument.

Material is deposited in the Micropalaeontology Laboratory, Indian Institute of Technology, Bombay under slide numbers: IIT B/15/K1-K12. 


\section{Results}

The lower part of the studied succession is devoid of foraminifera. The shale overlying the top lignite seam contains larger benthic foraminifera Halkyardia minima (Liebus, 1911), Linderina kutchiensis (Tewari, 1960), Lockhartia alveolata Silvestri, 1942 and Coskinolina along with the unnamed planktic foraminifer discussed in this study. The smaller benthic foraminifera in the assemblages include Trifarina advena rajasthanensis Kalia, 1978, Brizalina sp., Buliminella pupa (Terquem, 1882), Sagrina sp., Nonion sp., Nonionella sp., Quinqueloculina sp., Indicola rajasthanensis Singh \& Kalia, 1970, Tubulogenerina tubulifera (Parker \& Jones, 1863), Glandulina laevigata (d'Orbigny, 1826), Guttulina problema (d'Orbigny, 1826), Epistomaria rimosa (Parker \& Jones, 1865), Pararotalia curryi (Cushman, 1928), Elphidium sp. and Cibicides sp.. The distribution of foraminifera is shown in Figure 2. Some of the benthic foraminifera are illustrated in Plate 1 and views of the unnamed planktic foraminifer are provided in Plate 2. Thirty-two benthic taxa were identified from the mine section. The foraminiferal assemblage exhibits low diversity values of Fisher alpha $(\alpha \approx$ 1.5 to 7$)$ and Shannon-Weaver indices ( $\mathrm{H} \approx 1.3$ to 2.4). The percentage of RBF morphogroup varies from $20 \%$ to $60 \%$ in the mine section, and the remainder are the rounded benthic foraminifera.

\section{Discussion}

\section{Age}

The larger benthic foraminifera in the studied section include Halkyardia minima, Linderina kutchiensis and Lockhartia alveolata. These species are indicative of a Middle Eocene age and also occur in the Fulra Limestone (Bartonian) in adjoining sections of Kutch. Indicola rajasthanensis, a benthic foraminifer reported from Middle Eocene strata of Rajasthan (Singh \& Kalia 1970) and Kutch (Jauhri 1974), is also found in the Matanomadh mine. Wellpreserved dinoflagellate cysts including Homotryblium floripes (Deflandre \& Cookson, 1955), Cordosphaeridium cantharellum (Brosius, 1963) and Glaphyrocysta intricata (Eaton, 1961) in shales overlying the lignite beds in Matanomadh mine confirm a late Middle Eocene age for the upper part of the lignite mine (Jyoti Sharma, pers. comm. 2014).

\section{Palaeoenvironment}

The sedimentary succession of Matanomadh contains a low diversity assemblage of foraminifera. The presence of Nonion, Quinqueloculina, Cibicides, Elphidium, Rotalia and Pararotalia, together with a low abundance of larger benthic foraminifera, suggest water depths within 10-15 m. The RBF morphogroup exceeds $40 \%$ of the assemblage at many levels in the section. A high abundance of RBF is indicative of low-oxygen conditions (Bernhard 1986; Preece et al. 1999; Nigam et al. 2007; Reolid et al. 2008). The values of Fisher alpha $(\alpha)$ and Shannon-Weaver $(H)$ from the Matanomadh section fall in the normal marine-hypersaline lagoon and marsh, brackish marginal marine fields (solid grey circles in Fig. 3) given by Murray (2006). The pockets of restricted subbasins with development of carbonaceous shale and lignite are well established in Kutch (Biswas 1992). The Bartonian transgression led to major flooding in several peri-cratonic basins of India (Raju 2008). It led to the development of a carbonate platform in Kutch, referred to the Fulra Limestone. It was during this phase that Matanomadh was also flooded wherein restricted facies equivalent to the Fulra Limestone were deposited. Palynological and biomarker studies have established the occurrence of evergreen forests and high precipitation in the area (Dutta et al. 2011). The overall sedimentation was in a restricted basin with major contribution of plant materials and high run off in the beginning and marine transgression in the later part.

\section{Morphological description}

The unnamed foraminifer from Matanomadh is characterized by spherical tests with multiple and overlapping, subglobular to globular chambers (Pl. 2, figs f, g). The early trochospiral part is followed by streptospirally coiled chambers. It has areal apertures with rim (Pl. 2, figs a-e, h, m) and multiple sutural apertures in early whorls (Pl. 2, fig. o). The wall structure is cancellate and coarsely perforate and there is a strong development of pustules over it in the final chamber. (Pl. 2, figs $\mathrm{n}, \mathrm{o}$ ). The pustules are often developed on one side only, near the apertures and vary in shape from flattened to elongated and branched (Pl. 2, figs j, k, 1). These are occasionally developed on the penultimate chambers ( $\mathrm{Pl}$. 2, fig. i). A striking feature of the wall is the heterogeneous texture varying from coarsely perforate to restricted pores and pustular in the same ultimate or penultimate chambers. The tests are of small size and vary from $c .250$ to $c .400 \mu \mathrm{m}$.

\section{Benthic or planktic?}

The initial examination of the studied specimens under the optical microscope unambiguously identified them as Orbulinoides. The question of identity arose due to the atypical wall structure when seen under SEM. The opinions of specialists on the SEM micrographs varied. Three possible views were expressed: (1) Orbulinoides with some degenerate features; (2) planktic foraminifer; (3) benthic foraminifer related to Tretomphalus.

We differ from the view that it is a benthic foraminifer and likely related to Tretomphalus. The chambers of the reported foraminifer are overlapping, inflated and globular throughout the ontogeny, and do not have the 'Discorbis-like' early stage and umbilical aperture of Tretomphalus. The early trochospiral to later streptospiral coiling, the globular final chambers almost completely embracing the previous chambers, coarsely perforate walls and multiple sutural and areal apertures are all characteristics of the planktic foraminifera of the subfamily Porticulasphaerinae (see Banner 1982). It also bears a superficial resemblance to planktic foraminifera Globigerinatella insueta Cushman \& Stainforth, 1945 from the Miocene and thus further supports our interpretation that it is a planktic foraminifer.

\section{Similarities and differences}

The morphological characters, including the wall texture of the specimens of 'normal' $O$. beckmanni from the Fulra Limestone in the nearby Berwali section, conform to those described and illustrated by previous workers (for example, Samanta 1970; Premoli Silva et al. 2006). These are characterized by a spinose cancellate wall, trochospirally to streptospirally coiled chambers and multiple sutural apertures (Pl. 2, figs p, q, r). The size of the specimens varies from $c .400$ to $c$. $600 \mu \mathrm{m}$. The associated planktic foraminifera in Fulra Limestone include Acarinina rohri (Brönnimann \& Bermudez, 1953), Acarinina topilensis (Cushman, 1925), Pseudohastigerina micra (Cole, 1927), Streptochilus martini (Pijpers, 1933) and Catapsydrax unicavus Bolli, Loeblich \& Tappan, 1957.

The unnamed Matanomadh specimens bear a close resemblance to Orbulinoides in having inflated chambers, streptospiral coiling in the late stage, coarsely perforate wall, areal apertures in final chambers and sutural apertures in the inner spire. They differ from the typical $O$. beckmanni in possessing overlapping chambers and in the absence of clear evidence of embedded spines. Another distinct difference from Orbulinoides is the non-uniform nature of the wall texture even within the same chambers (final or penultimate).

Proto Decima \& Bolli (1970) illustrated the pustular nature of the wall in Globigerinatheka euganea, the ancestor of Orbulinoides beckmanni. The reported form thus bears closest similarity to Orbulinoides except for the wall texture. We realize that some 


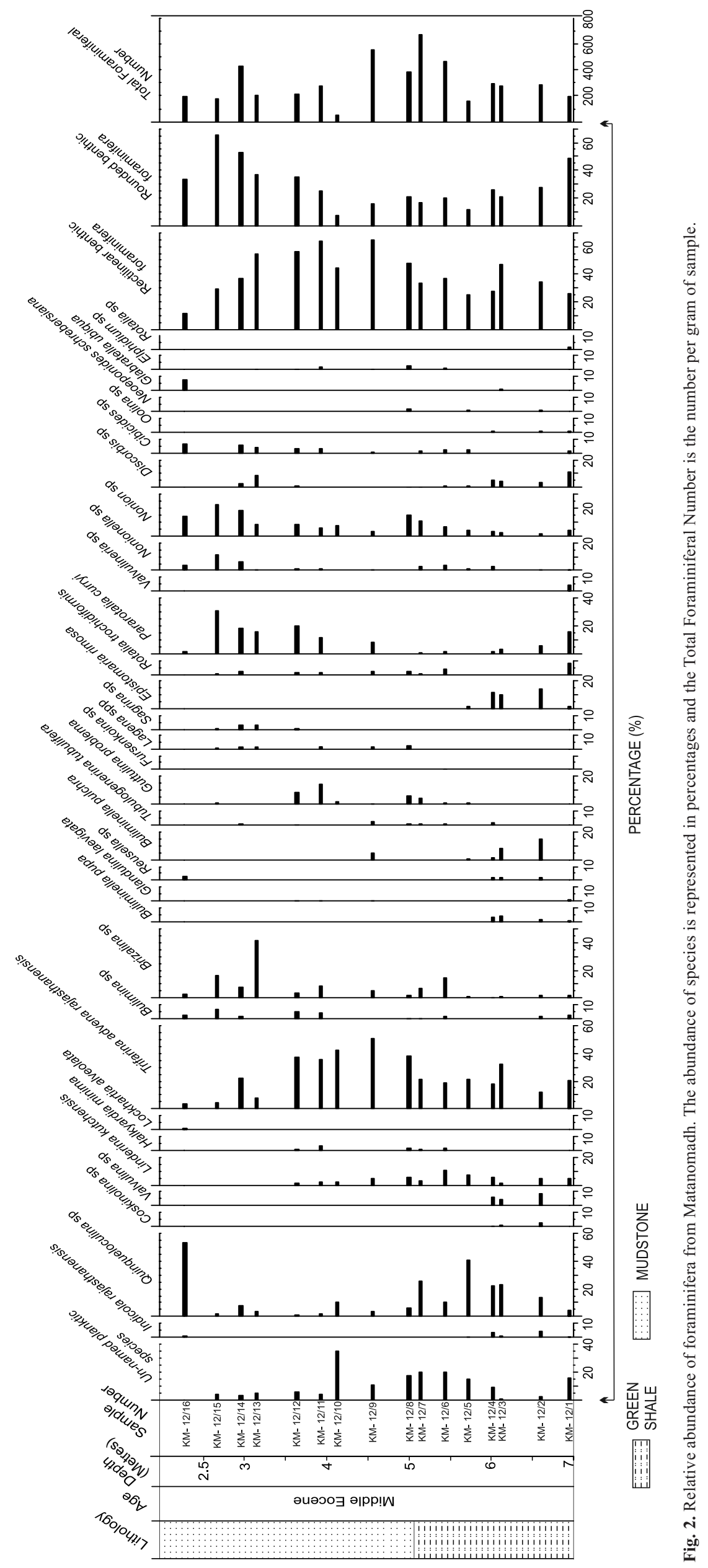




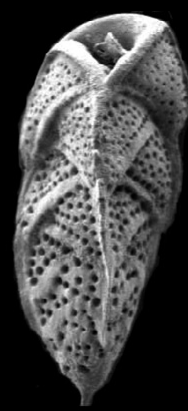

$\overline{50 \mu \mathrm{m}}$

a

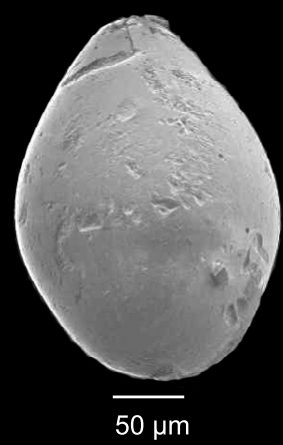

e
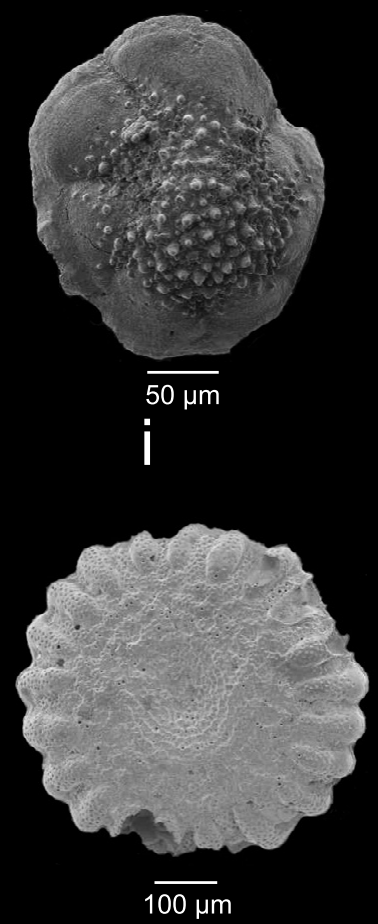

m

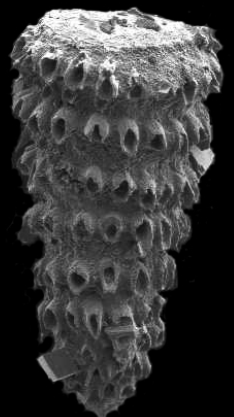

$50 \mu \mathrm{m}$

b

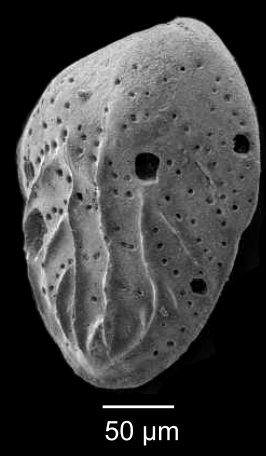

f
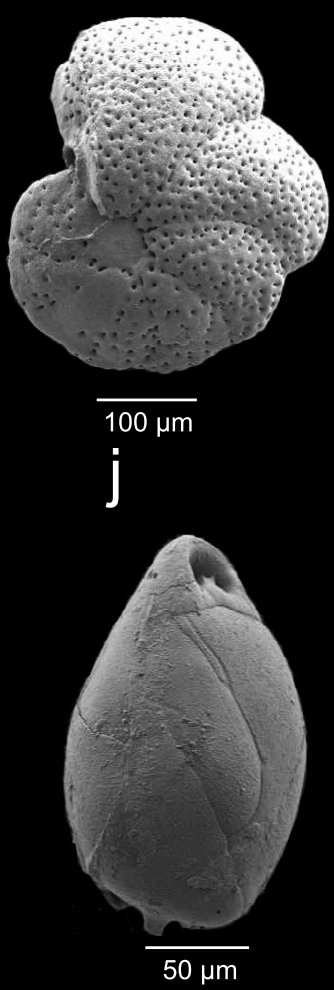

n

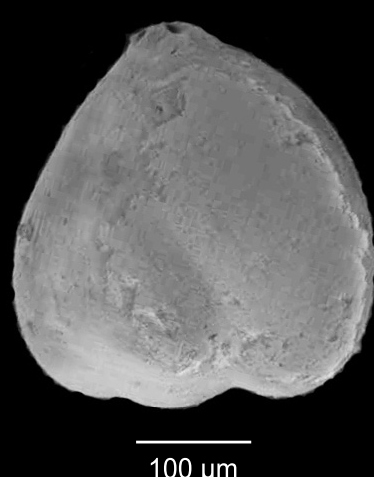

C

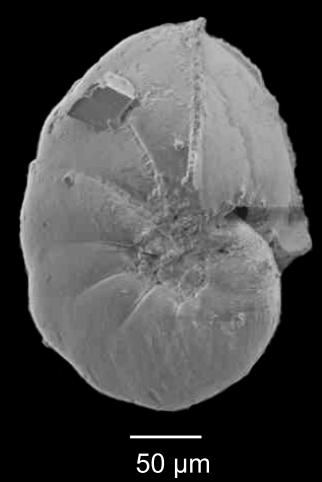

g
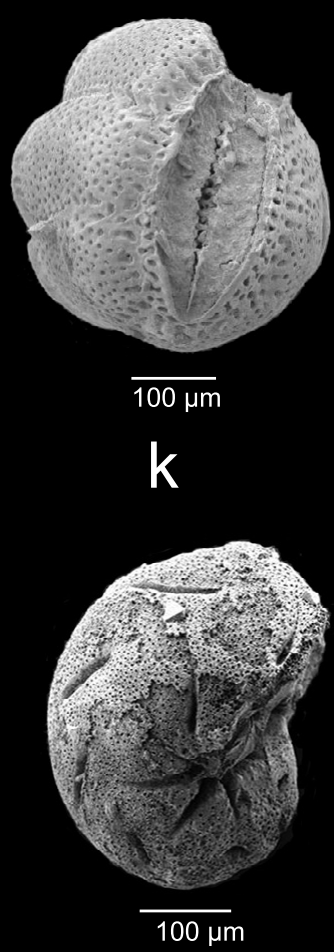

O
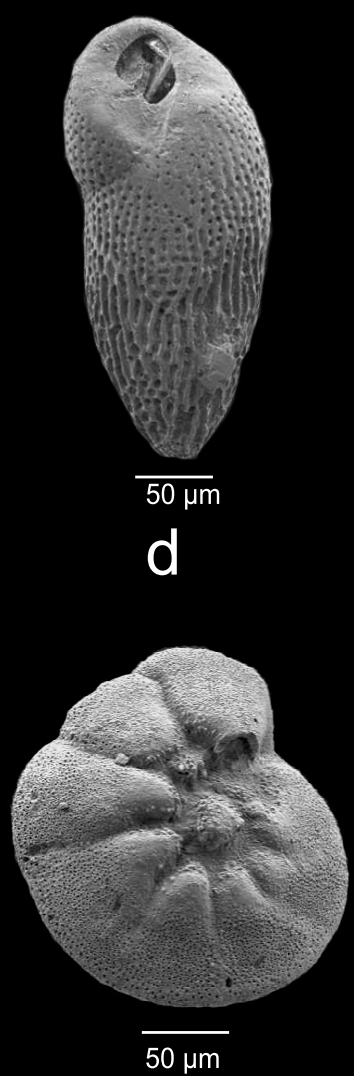

h
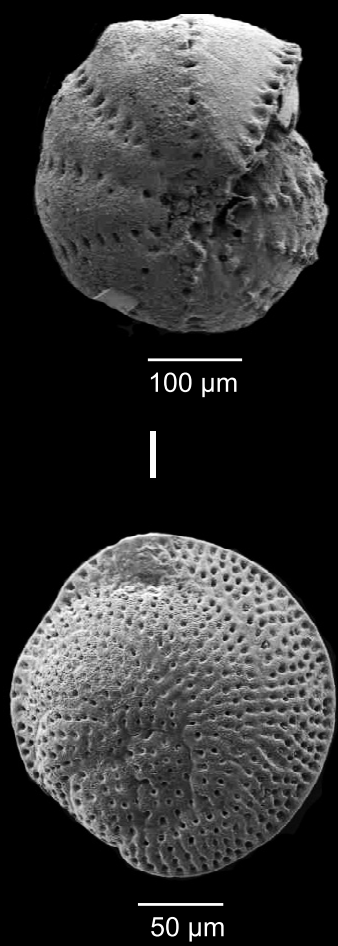

$p$

Explanation of Plate 1. Selected benthic foraminifera from Matanomadh: fig. a. Trifarina advena rajasthanensis; fig. b. Tubulogenerina tubulifera; fig. c. Guttulina problema; fig. d. Buliminella pupa; fig. e. Glandulina laevigata; fig. f. Brizalina sp.; fig. g. Nonionella sp.; fig. h. Rotalia sp.; fig. i. Rotalia trochidiformis; fig. j. Cibicides sp.; fig. k. Indicola rajasthanensis; fig. l. Elphidium sp.; fig. m. Linderina kutchiensis; fig. n. Quinqueloculina sp.; fig. o. Epistomaria rimosa; fig. p. Glabratella ubiqua. 

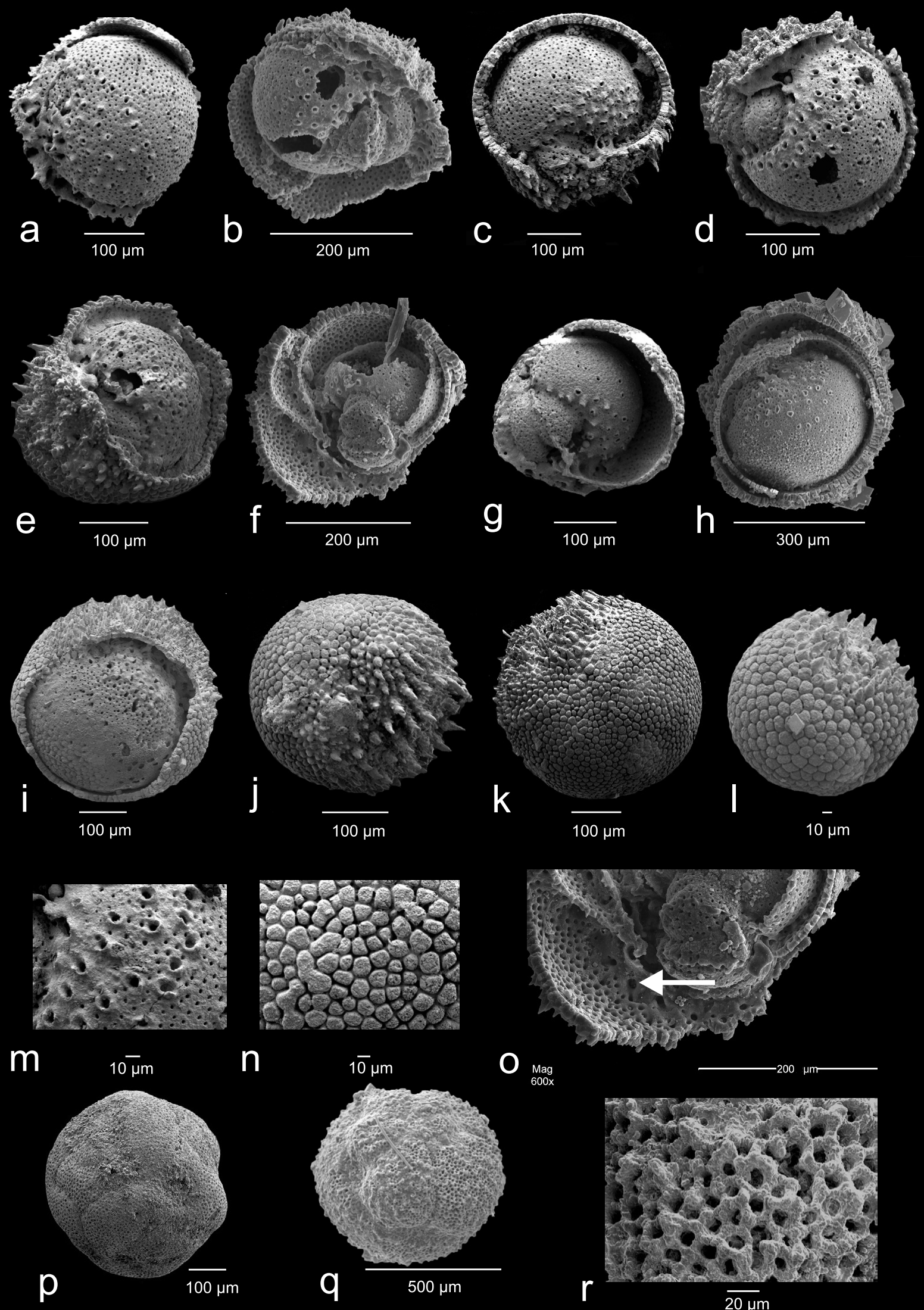

n
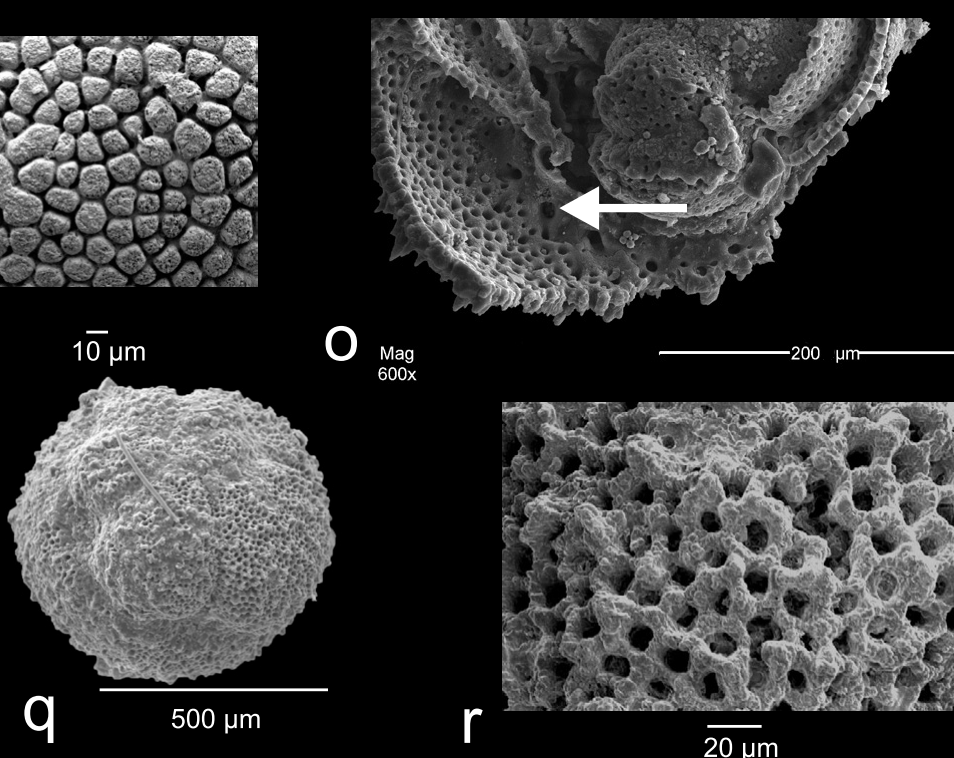

$\mathrm{O}_{\text {mag }}$

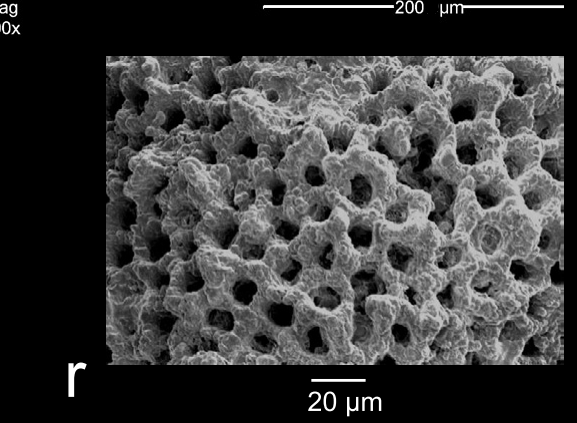

Explanation of Plate 2. Unnamed planktic foraminifera of this study showing (figs a-e, $\mathbf{g}, \mathbf{h}$ ) spherical test, areal apertures; (fig. f) multiple overlapping chambers; (fig. i) development of pustules in final chamber and occasionally in the penultimate chamber; (figs j-l) flattened and bifurcated pustules developed over the earlier wall structure; (fig. m) enlarged view of the areal apertures; (fig. n) flattened pustules; (fig. o) multiple sutural apertures indicated by an arrow and cancellate wall texture. (figs p-r) specimens of $O$. beckmanni from Fulra Limestone. 


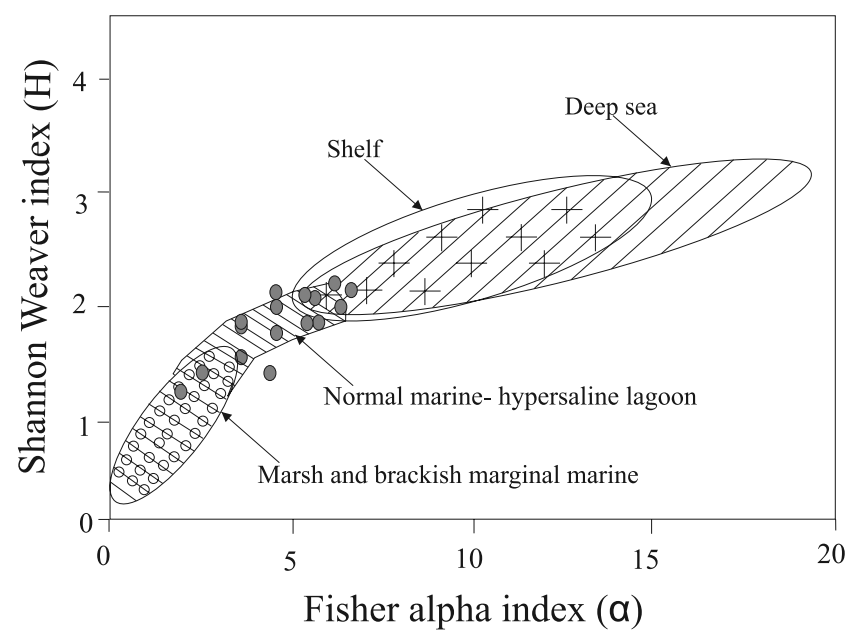

Fig. 3. Plot of Fisher $(\alpha)$ v. Shannon-Weaver $(\mathrm{H})$ diversity indices of foraminifera from Matanomadh. Most samples (indicated by filled circles) fall in the normal marine to hypersaline lagoon area (Murray 2006).

issues remain unresolved and therefore prefer to keep the nomenclature open.

\section{Is the atypical wall texture due to environmental stress?}

Aberrant planktic foraminifera have been reported in Recent as well as fossil assemblages. Aberration in Orbulina universa d'Orbigny, 1839 is documented by Robbins (1988) in an ocean margin environment versus normal morphology of the same species in an open ocean environment. The formation of atypical wall texture may be attributed to various possible causes, including gametogenesis, diagenesis or aberration due to unfavourable environmental conditions. In gametogenesis only the last chamber of the foraminiferal test is affected (Lohmann 1995); however, the pustular wall in the studied specimens occurs both in the final and penultimate chambers. Gametogenesis occurs in the last ontogenic stage when the species moves to a deeper-water habitat. It is intriguing whether the specimens developed the pustular wall because of gametogenesis or not, given the foraminiferal assemblage, lithology and palaeogeographical setting of the Matanomadh section which indicate a shallow-marine depositional setting. The specimens have a 'frosty' preservation (Sexton et al. 2006) and are free from any diagenetic encrustation at least in the lower part of the succession which is dominated by shales. The diagenetic alteration has taken place at certain levels in the section due to which the external view of the original wall structure of the reported planktic foraminifer is obscured completely. Thus, the possibility of diagenesis can be ruled out as a cause of the development of the atypical wall texture of the reported planktic foraminifer of Matanomadh. The cause of aberration in wall texture could be the restricted marine environment of deposition. It is intriguing as to why the unnamed, Orbulinoides-like foraminifer is the only planktic foraminifer in this environmental setting. It is observed that at several stratigraphic intervals in Early and Middle Eocene age sediments of western India Acarinina, Subbotina, Chiloguembelina, Streptochilus or Jenkinsina (Chattoraj et al. 2009; Saraswati et al. 2012; Keller et al. 2013) are the only planktic foraminifera in assemblages otherwise dominated by benthic foraminifera.

\section{Conclusion}

A restricted marine Middle Eocene (Bartonian) succession of Kutch in western India contains an atypical planktic foraminifer bearing close resemblance with Orbulinoides. Indistinguishable from Orbulinoides in overall morphology under the optical microscope, the wall texture under scanning electron microscope distinguishes it from this genus. The aberrant wall texture was possibly due to the environmental stress of a near-shore, brackish-water, semi-enclosed depositional setting in the warm and humid climate of India in the Middle Eocene. It remains unresolved why the reported taxon is the only planktic foraminifer in the assemblage.

\section{Acknowledgements and Funding}

We would like to thank Professors Paul Pearson, Ellen Thomas, M.S. Srinivasan, Bridget Wade, J. Debenay and Dr Vlasta Premec Fucek who offered their views on the SEM images, and to Professor Rodolfo Coccioni and an anonymous reviewer for their valuable comments which helped improve the manuscript. We would like to thank Dr Jyoti Sharma for sharing her ongoing research on dinoflagellates from the Matanomadh mine section. SK thanks the University Grants Commission for providing a research grant to carry out the study.

\section{Scientific editing by Sigal Abramovich}

\section{References}

Banner, F.T. 1982. A classification and introduction to Globigerinacea. In: Banner, F.T. \& Lord, A.R. (eds) Aspects of Micropaleontology. George Allen \& Unwin, London, 142-239.

Berggren, W.A., Kent, D.V., Swisher, C.C. \& Aubry, M.P. 1995. A revised Cenozoic geochronology and chronostratigraphy. Geochronology time scales and global stratigraphic correlation. In: Berggren, W.A., Kent, D.V. Aubry, M-P. \& Hardenbol, J. (eds) Geochronology, Time Scales, and Global Stratigraphic Correlation. [COMP: editors and volume title added] SEPM Special Publication, 54, 129-212.

Bernhard, J.M. 1986. Characteristic assemblages and morphologies of benthic foraminifera from anoxic, organic-rich deposits: Jurassic through Holocene. Journal of Foraminiferal Research, 16, 207-215.

Biswas, S.K. 1992. Tertiary stratigraphy of Kutch. Journal of the Palaeontological Society of India, 37, 1-29.

Biswas, S.K. \& Raju, D.S.N. 1971. Note on the rock stratigraphic classification of the Tertiary sediments of Kutch. Quarterly Journal of the Geological, Mining and Metallurgical Society of India, 43, 177-180.

Blow, W.H. \& Saito, T. 1968. The morphology and taxonomy of Globigerina mexicana Cushman, 1925. Micropaleontology, 14, 357-360.

Chattoraj, S.L., Banerjee, S. \& Saraswati, P.K. 2009. Glauconites from the Late Paleocene-early Eocene Naredi Formation, Western Kutch and their genetic implications. Journal of the Geological Society of India, 73, 567-574.

Cordey, W.G. 1968. Morphology and phylogeny of Orbulinoides beckmanni (Saito, 1962). Palaeontology, 11, 371-375.

Dutta, S., Matthew, R.P. et al. 2011. Petrology, palynology and organic geochemistry of Eocene lignite of Matanomadh, Kutch Basin, western India: Implications to depositional environment and hydrocarbon source potential. International Journal of Coal Geology, 85, 91-102.

Hammer, Ø., Harper, D.A.T. \& Ryan, P.D. 2001. PAST: Paleontological statistics software package for education and data analysis. Palaeontologia Electronica, 4, 1-9.

Jauhri, A.K. 1974. Occurrence of Indicola rajasthanensis Singh and Kalia in Lutetian beds of the Vinjhan-Miani area, southwestern Kutch, Gujarat. Current Science, 43, 82-83.

Kalia, P. 1978. Buliminds from the Middle Eocene of Rajasthan, India. Journal of the Palaeontological Society of India, 21-22, 44-48.

Keller, G., Khozyem, H., Saravanan, N., Adatte, T., Bajpai, S. \& Spangenberg, J. 2013. Biostratigraphy and foraminiferal paleoecology of the early Eocene Naredi Formation, SW Kutch, India. Geological Society of India (Special Publication), 1, 183-196.

Loeblich, A.R. \& Tappan, H. 1987. Foraminiferal Genera and their Classification. Vols 1 \& 2. Van Nostrand Rienhold Co., New York.

Lohmann, G.P. 1995. A model for variation in the chemistry of planktonic foraminifera due to secondary calcification and selective dissolution. Paleoceanography, 10, http://doi.org/10.1029/95PA00059

Mohan, M. \& Soodan, K.S. 1970. Middle Eocene planktic foraminiferal zonation. Micropaleontology, 16, 37-46.

Murray, J. 2006. Ecology and Applications of Benthic Foraminifera. Cambridge University Press

Murray, J.W. \& Wright, C.A. 1974. Palaeogene foraminiferida and palaeoecology, Hampshire and Paris Basins and the English Channel. Special Papers in Palaeontology, 14, 1-129.

Nagy, J. 1992. Environmental significance of foraminiferal morphogroups in Jurassic North Sea deltas. Palaeogeography Palaeoclimatology Palaeoecology, 95, 111-134.

Nigam, R., Mazumder, A., Henriques, P.J. \& Saraswat, R. 2007. Benthic foraminifera as proxy for oxygen-depleted conditions off the central wes coast of India. Journal of the Geological Society of India, 70, 1047-1054.

Preece, R.C., Kaminski, M.A. \& Dignes, T.W. 1999. Miocene benthonic foraminiferal morphogroups in an oxygen minimum zone, offshore Cabinda In: Cameron, N.R., Bate, R.H. \& Clure, V.S. (eds) The Oil and Gas Habitats of the South Atlantic.[COMP: editors and volume title added] Geological 
Society, London, Special Publications, 153, 267-282, http://doi.org/10.1144/ GSL.SP.1999.153.01.16

Premoli Silva, I., Wade, B.S. \& Pearson, P.N. 2006. Taxonomy of Globigerinatheka and Orbulinoides. In: Pearson, P.N., Olsson, R.K., Huber, B.T., Hemleben, C. \& Berggren, W.A. (eds) Atlas of Eocene Planktonic Foraminifera. Cushman Foundation Special Publication, 41, 169-212.

Proto Decima, F. \& Bolli, M.H. 1970. Evolution and variability of Orbulinoides beckmanni (Saito). Ecologae Geologicae Helvetiae, 63, 883-905.

Raju, D.S.N. 2008. Phanerozoic Cycles of Sea-Level Change on Indian Plate: An overview with a Base Chart. GEO India Convention \& Exhibition, New Delhi, India, 1-5.

Reolid, M., Rodriguez Tovar, F.J., Nagy, J. \& Oloriz, F. 2008. Benthic foraminiferal morphogroups of mid to outer shelf environments of the Late Jurassic (Prebetic zone, southern Spain): Characterization of biofacies and environmental significance. Palaeogeography, Palaeoclimatology, Palaeoecology, 261, 280-299.

Robbins, L.L. 1988. Environmental significance of morphologic variability in open-ocean versus ocean-margin assemblages of Orbulina universa. Journal of Foraminiferal Research, 18, 326-333.
Saito, T. 1962. Eocene planktonic foraminifera from Hahajima (Hillsborough Island). Transactions and Proceedings of the Paleontological Society of Japan, New Series, 45, 209-225.

Samanta, B.K. 1970. Middle Eocene planktonic foraminifera from Lakhpat, Cutch, western India. Micropaleontology, 16, 185-215.

Saraswati, P.K., Sarkar, U. \& Banerjee, S. 2012. Nummulites solitarius-Nummulites burdigalensis lineage in Kutch with remarks on the age of Naredi Formation. Journal of the Geological Society of India, 7, 476-482.

Sexton, P.F., Wilson, P.A. \& Pearson, P.N. 2006. Microstructural and geochemical perspectives on planktic foraminiferal preservation: 'Glassy' versus 'frosty'. Geochemical Geophysical Geosystems, 7, Q12P19, http://doi. org/10.1029/2006GC001291

Singh, S.N. \& Kalia, P. 1970. A new planktonic foraminifer from the Middle Eocene of India. Micropaleontology, 16, 76-82.

Wade, B.S., Pearson, P.N., Berggren, W.A. \& Pälike, H. 2011. Review and revision of Cenozoic tropical planktonic foraminiferal biostratigraphy and calibration to the geomagnetic polarity and astronomical time scale. Earth Science Reviews, 104, 111-142. 